Volume 20 Number 1 June 2020. P.167-190

https://doi.org/10.30603/au.v20i1.1338

\title{
The Existence of Profit Growth in Companies in The Jakarta Islamic Index (JII) (2016-2018)
}

\author{
Sofhian \\ IAIN Sultan Amai Gorontalo
}

\begin{abstract}
This study aims to determine the partial profit growth of company stock prices (companies registered in the Jakarta Islamic Index - JII). The article is the result of stock analysis and annual financial statements of companies that enter the 2016-2018 Jakarta Islamic Index, by using a quantitative research. The sample used was obtained from 90 Jakarta Islamic Index companies using the simple regression analysis method. From the results of the hypothesis test, the variable earnings growth showed no significant effect on stock prices at companies listed on the Jakarta Islamic Index (JII). From the results of partial testing between earnings growth variables and stock price variables, the T count is smaller than the T table with a value of $0.436<1.987$ and a sig value of 0.664 is greater than 0.05 . Therefore, it can be said that the profit growth variable does not have a significant effect on stock prices. According to the researchers, this occurs because there are other influences, one of which is the fluctuation of the rupiah exchange rate against foreign currencies.
\end{abstract}

\section{Eksistensi Pertumbuhan Laba pada Perusahaan di Jakarta Islamic Index (JII) (Tahun 2016-2018)}

\begin{abstract}
Abstrak
Penelitian ini bertujuan mengetahui pertumbuhan laba secara parsial terhadap harga saham perusahaan (perusahaan terdaftar di Jakarta Islamic Index - JII). Artikel merupakan hasil analisa saham dan laporan keuangan tahunan perusahaan yang masuk Jakarta Islamic Index tahun 20162018, jenis penelitian ini adalah penelitian kuantitatif. Sampel yang digunakan diperoleh dari 90 perusahaan Jakarta Islamic Index dengan menggunakan metode analisis regresi Sederhana. Dari hasil uji hipotesis, variabel pertumbuhan laba menunjukan tidak berpengaruh signifikan terhadap harga saham pada perusahaan terdaftar di Jakarta Islamic Index (III). Dari hasil pengujian secara parsial antara variabel pertumbuhan laba dan variabel harga saham menunjukan T hitung lebih kecil dari pada T tabel dengan nilai 0,436 <1,987 dan memiliki nilai sig sebesar 0,664 lebih besar dari 0,05 . Jadi dapat disimpulkan variabel pertumbuhan laba tidak berpengaruh signifikan terhadap harga saham, Menurut peneliti, ini terjadi dikarenakan terdapat pengaruh lain salah satunya fluktuasi kurs rupiah terhadap mata uang asing.
\end{abstract}

Kata Kunci: laba, saham, pertumbuhan ekonomi islam

Author correspondence

Email: fiantomare@yahoo.co.id

_Available online at http://journal.iaingorontalo.ac.id/index.php/au/index 


\section{A. Pendahuluan}

Pasar modal kini hadir sebagai sarana yang efektif untuk mempercepat pertumbuhan perusahaan. Hal ini dimungkinkan karena pasar modal merupakan instrumen keuangan penting dalam suatu perekonomian, yang berfungsi memobilisasi dana dari masyarakat ke sektor produktif (perusahaan). Permadhy menjelaskan pasar modal bermanfaat untuk perluasan usaha, memperbaiki struktur modal, mendorong laju pembangunan, mendorong investasi, dan memperoleh dividen bagi yang memiliki saham dan bunga tetap atau bunga mengambang bagi pemegang obligasi.

Pasar modal merupakan pasar untuk berbagai instrumen keuangan jangka panjang yang bisa diperjualbelikan, baik surat utang (obligasi), ekuiti (saham), reksa dana, instrumen derivatif maupun instrumen lainnya. Pasar modal merupakan sarana pendanaan bagi perusahaan maupun institusi lain (misalnya pemerintah), dan sebagai sarana bagi kegiatan berinvestasi. ${ }^{1}$ Dengan demikian, pasar modal memfasilitasi berbagai sarana dan prasarana kegiatan jual beli dan kegiatan terkait lainnya. Instrumen keuangan yang diperdagangkan di pasar modal merupakan instrumen jangka panjang (jangka waktu lebih dari 1 tahun) seperti saham, obligasi, waran, right, reksa dana, dan berbagai instrumen derivatif seperti option, futures, dan lain-lain. Hal tersebut menjadi alternatif yang disukai perusahaan untuk mencari dana.

Pasar modal merupakan salah satu penggerak utama perekonomian dunia termasuk Indonesia, melalui pasar modal perusahaan dapat memperoleh dana untuk melakukan kegiatan perekonomiannya. Perkembangan pasar modal syariah yang baik belum tentu menunjukkan tingkat Return dan Risk saham syariah lebih baik dari saham konvensional. Seberapa besar perbedaan tingkat Return dan Risk saham konvensional dan saham syariah juga perlu diketahui oleh investor untuk melakukan investasi. Berdasarkan uraian yang telah disebutkan di atas maka

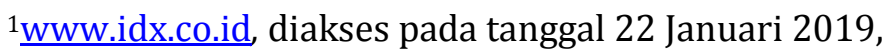


permasalahan yang ingin dikaji dalam penelitian yaitu apakah terdapat perbedaan antara return dan risk antara saham syariah dengan saham konvensional. ${ }^{2}$

Terdapat beberapa teori yang menggambarkan tentang pasar modal Syariah, sebagaimana dalam penelitian berikut ini, Berdasarkan hasil pemindaian beberapa jurnal-jurnal, beberapa topik yang teridentifikasi sebagai referensi penelitian ini pada pasar modal syariah. Topik yang paling mendominasi adalah tentang perbandingan kinerja pasar modal syariah dan pasar modal konvensional, yang didiskusikan dalam 10 judul penelitian (Ho et al., 2014; Al Khazali et al., 2014; Merdad et al., 2015; Charles et al., 2015; Rizvi et al., 2014, Dewandaru et al., 2014, Majid dan Maulana, 2012; Majid dan Maulana, 2012, Kabir et al., 2017; dan Henda dan Taher, 2017). Topik ini menarik karena hingga saat ini masih ada sebagian peneliti yang menyangkal keberadaan pasar modal syariah dan berpendapat bahwa penelitian mengenai pasar modal syariah adalah hal yang mengada-ada. Hasil perbandingan kinerja tersebut bervariasi. Terdapat 6 penelitian yang memberikan bukti empiris keunggulan pasar modal syariah dibandingkan pasar modal konvensional (Ho et al., 2014; Al Khazali et al., 2014; Mohammad dan Ashra, 2015; Masih et al., 2018; Kabir et al., 2017; dan Nainggolan et al., 2016) sedangkan 2 penelitian lainnya menyimpulkan bahwa berinvestasi di pasar modal syariah lebih berisiko (Charles et al., 2015 dan Nainggolan et al., 2016). Selain itu, terdapat juga 2 penelitian yang menginvestigasi hubungan kausalitas antara pasar modal syariah dengan pasar modal konvensional (Ajmi et al., 2014 dan Majdoub dan Mansour., 2014). Dengan demikian, eksistensi pasar modal syariah dapat dibuktikan melalui berbagai temuan empiris tersebut, sehingga menepis tudingan bahwa topik pasar modal syariah adalah hal yang tidak layak untuk diteliti.

Artikel ini juga mengindentifikasi berbagai teknik pengukuran kinerja pasar modal yang digunakan dalam berbagai penelitian. Total terdapat 8 teknik yang disajikan yaitu Al Khazali et al (2014), Aloui et al (2015), Dewandaru et al (2015), Rizvi et al (2014), Dewandaru et al (2014), Ajmi et al (2014), Abbes dan Trichilli (2015), dan Nakib et al (2017). Teknik tersebut berbasis analisis

${ }^{2}$ Herni Ruliatul Kasanah Saparila Worokinasih, Jurnal Administrasi Bisnis (JAB)/Vol. 58 No.2 Mei 2018, h.2 
teknikal. Penulis belum menemukan penelitian yang menggunakan variabel fundamental berbasis data laporan keuangan untuk mengukur kinerja sekuritas. Ini merupakan peluang sekaligus tantangan bagi para peneliti akuntansi untuk mengisi varian baru dalam pengukuran kinerja sekuritas berbasis data akuntansi.

Satu hal menarik yang disorot dalam penelitian tentang pasar modal syariah penggunaan perspektif masa krisis dalam model penelitian. Terdapat 9 penelitian yang menguji kinerja pasar modal syariah pada saat krisis, yaitu Ho et al (2014), Al Khazali et al (2014), Charles et al (2015), Dewandaru et al (2014), Abbes dan Trichilli (2015), Kumar (2017), Shaharuddin et al (2018), Henda dan Taher (2017), dan Kabir et al (2017). Temuan menariknya adalah bahwa pada saat krisis, justru pasar modal syariah memiliki kinerja yang lebih unggul dibandingkan konvensional (Kabir et al., 2017 dan Nainggolan et al., 2016), sehingga peneliti tersebut menyimpulkan bahwa pilihan berinvestasi di pasar modal syariah merupakan pilihan investasi untuk tipe investor konservatif.

Harga saham merupakan salah satu indikator keberhasilan pengelolaan perusahaan, jika harga saham suatu perusahaan selalu mengalami kenaikan, maka investor atau calon investor menilai bahwa peruasahaan berhasil dalam mengelola usahanya. Kepercayaan investor atau calon investor sangat bermanfaat bagi emiten, karena semakin banyak orang yang percaya terhadap emiten maka keinginan untuk berinvestasi pada emiten semakin kuat. Semakin banyak permintaan terhadap saham suatu emiten maka dapat menaikkan harga saham tersebut. Jika harga saham yang tinggi dapat dipertahankan maka kepercayaan investor atau calon investor terhadap emiten juga semakin tinggi dan hal ini dapat menaikkan nilai emiten. Sebaliknya, jika harga saham mengalami penurunan terusmenerus berarti dapat menurunkan nilai emiten dimata investor atau calon investor. Biasanya kenaikan laba merupakan suatu sinyal kepada investor bahwa manajemen perusahaan meramalkan suatu penghasilan yang baik dimasa mendatang. Oleh karena itu dengan nilai perusahaan yang tinggi maka akan semakin banyak investor yang tertarik untuk menginvestasikan modalnya karena peluang mendapatkan pengembalian yang tinggi. 
Dengan adanya ISSI masyarakat tidak lagi salah paham terhadap dimana semula pemikiran saham syariah yang dimiliki Indonesia hanya berjumlah 30 saham yang termasuk dalam Jakarta Islamic Index (JII) saja ternyata masih banyak saham syariah lainnya yang terdaftar dalam ISSI. ${ }^{3}$ terdapat sebelas indeks harga saham yang terdaftar, yakni : indeks individual, indeks harga sektoral, indeks harga saham gabungan, indeks LQ45 dan index JII salah satu indeks saham yang berlandaskan syariah yang sering disebut Jakarta Islamic Index(JII)

Jakarta Islamic index adalah ( JII ) adalah salah satu dari 11 indeks saham yang ada di Indonesia yang menghitung indeks rata-rata saham untuk jenis sahamsaham yang berbasis syariah. Pembentukan instrument syariah ini untuk mendukung pembentukan pasar modal syariah yang kemudian diluncurkan di jakarta 14 maret 2003. Saham yang masuk dalam JII berjumlah 30 saham yang memenuhi kriteria syariah.Berikut table saham yang masuk dalam Jakarta Islamic Index. Jumlah perusahaan yang berada di jakarta islamic index di tiga tahun terakhir.

Tabel 1.2

\begin{tabular}{|l|l|l|}
\hline No & Tahun & Jumlah Perusahaan \\
\hline 1 & 2016 & 30 perusahaan \\
\hline 2 & 2017 & 30 perusahaan \\
\hline 3 & 2018 & 30 perusahaan \\
\hline
\end{tabular}

Sumber: www.idx.com

Alasan penulis memilih objek penelitian Jakarta Islamic Index ( JII ) karena JII merupakan index saham yang memenuhi kriteria di pasar modal berdasarkan sistem syariah Islam hingga mendapatkan perhatian yang cukup besar terhadap kebangkitan ekonomi Islam saat ini. Saham-saham tersebut juga merupakan saham-saham kapitalisasi besar sehingga penelitian ini terhindar dari potensi penggunaan saham tidur. ${ }^{4}$

${ }^{3}$ Muthoharoh, Sutapa, Jurnal Akuntansi Indonesia, Vol. 3 No. 2 Juli 2014

4 Rusdin, Pasar modal teori, masalah, dan kebijakan dalam praktik,(Bandung, Alfabeta, 2008). hal. 133 
Berdasarkan uraian hasil penelitian di atas, peneliti tertarik untuk mengangkat judul penelitian "Eksistensi Pertumbuhan Laba pada Perusahaan di Jakarta Islamic Index (JII) tahun 2016-2018

\section{B. Tinjauan Teori dan Konsep}

\section{Pasar Modal}

Pasar modal adalah ( capital market) merupakan pasar untuk berbagi instrument keuangan jangka panjang yang bisa diperjual belikan, baik dalam bentuk utang maupun modal sendiri. Prinsip instrument pasar modal syariah berbeda dengan pasar modal konvensional. Sejumlah instrumen syariah di pasar modal sudah diperkenalkan pada masyarakat, misalnya saham yang berprinsipkan syariah dimana kriteria saham syariah adalah saham yang dikeluarkan perusahaanyang melakukan usaha yang sesuai dengan prinsip syariah. ${ }^{5}$

Pasar modal adalah perdagangan instrument keuangan (sekuritas) jangka panjang, antara lain: dalam bentuk modal sendiri (stock) maupun utang (bonds); baik yang diterbitkan oleh pemerintah (public authorities) maupun oleh perusahaan swasta (private sector). Sedangkan pasar modal syariah merupakan tempat atau sarana bertemunya penjual dan pembeli instrumen keuangan syariah yang dalam berinteraksi berpedoman pada ajaran islam dan menjauhi hal-hal yang dilarang, seperti penipuan dan penggelapan ${ }^{6}$

Menurut Joel G. Siegel dan Jae K. Shim pasar modal adalah perdagangan utang jangka panjang dan saham perusahaan. Menurut R.J. Shook pasar modal merupakan sebuah pasar tempat dana-dana modal, seperti ekuitas dan utang, diperdagangkan ${ }^{7}$

Pasar modal juga mampu menjadi tolak ukur kemajuan perekonomian suatu negara. Pasar modal memungkinkan percepatan pertumbuhan ekonomi dengan memberikan kesempatan bagi perusahan untuk dapat memanfaatkan

5 Heri sudarsono, Bank dan Lembaga keuangan syariah deskripsi dan ilustrasi, (Yogyakarta, Ekonosia, 2012).hal.199

6 Ahmad Rodoni dan Abdul Hamid Lembaga Keuangan Syariah, Zikrul Hakim, Jakarta Timur hal. 123

7 Irham Fahmi, Bank dan lembaga keuangan lainnya teori dan aplikasi, (Bandung, Alfabeta , 2014). Hal.242 
dana langsung dari masyarakat tanpa harus menunggu tersedianya dana dari operassi perusahan.

\section{Pasar Modal Syariah}

Pasar modal syariah (Islamic stock exchange) adalah kegiatan yang berhubungan dengan perdagangan efek syariah perusahaan public yang berkaitan dengan efek yang diterbitkannya serta lembaga profesi yang berkaitan dengannya, di mana semua produk dan mekanisme operasionalnya tidak bertentangan denga syariat Islam.Pasar modal syariah dapat juga diartikan adalah pasar modal yang menerapkan prinsip-prinsip syariah.

Sistem mekanisme pasar modal konvensional yang mengandung riba, maisir dan gharar selama ini telah menimbulkan keraguan dikalangan umat islam. Pasar modal islam dikembangkan dalam rangka mengkomodir kebutuhan umat muslim di Indonesia yang ingin melakukan investasi di pasar modal sesuai dengan prinsip syariah. Hal ini berkenaan dengan anggapan di kalangan sebagai umat islam sendiri bahwa berinvestasi di pasar modal di satu sisi merupakan sesuatu yang tidak diperbolehkan (diharamkan) berdasarkan ajaran islam, sementara di sisi lain Indonesia perlu memperhatikan dan menarik minat investor mancanegara untuk berinvestasi di pasar modal Indonesia, terutama investor dari Negaranegara Timur Tengah yang diyakini merupakan investor potensial.

Berdasarkan definisi tersebut, terminologi pasar modal syariah dapat diartikan sebagai kegiatan dalam pasar modal sebagaimana yang diatur dalam UUPM yang tidak bertentangan dengan prinsip syariah.Oleh karena itu, pasar modal syariah bukanlah suatu sistem yang terpisah dari sistem pasar modal secara keseluruhan.Secara umum kegiatan Pasar Modal Syariah tidak memiliki perbedaan dengan pasar modal konvensional, namun terdapat beberapa karakteristik khusus Pasar Modal Syariah yaitu bahwa produk dan mekanisme transaksi tidak bertentangan dengan prinsip-prinsip syariah.

Penerapan prinsip syariah di pasar modal tentunya bersumberkan pada $\mathrm{Al}$ Quran sebagai sumber hukum tertinggi dan Hadits Nabi Muhammad SAW. Selanjutnya, dari kedua sumber hukum tersebut para ulama melakukan penafsiran yang kemudian disebut ilmu fiqih.Salah satu pembahasan dalam ilmu fiqih adalah pembahasan tentang muamalah, yaitu hubungan diantara sesama manusia terkait 
perniagaan.Berdasarkan itulah kegiatan pasar modal syariah dikembangkan dengan basis fiqih muamalah.Terdapat kaidah fiqih muamalah yang menyatakan bahwa Pada dasarnya, semua bentuk muamalah boleh dilakukan kecuali ada dalil yang mengharamkannya.Konsep inilah yang menjadi prinsip pasar modal syariah di Indonesia. ${ }^{8}$

Pengkajian ulang akan dilakukan dalam waktu 6 (enam) bulan sekali dengan penentuan komponen indeks pada awal bulan Januari dan Juli setiap tahunnya. Sedangkan perubahan pada jenis usaha emiten akan dimonitoring secara terus menerus berdasarkan data-data publik yang tersedia. Perhitungan Jakarta Islamic Index (JII) dilakukan oleh Bursa Efek Jakarta (BEJ) dengan menggunakan metode perhitungan indeks yang telah ditetapkan oleh Bursa Efek Jakarta (BEJ), yaitu dengan bobot kapitalisasi pasar (market cap weighted). Perhitungan indeks ini juga mencakup penyesuaian-penyesuaian (adjustment) akibat berubahnya data emiten yang disebabkan oleh aksi korporasi. Jakarta Islamic Index (JII) menggunakan tanggal awal perhitungan 1 Januari 1995 dengan nilai awal 100 (seratus). ${ }^{9}$

\section{Perkembangan Pasar Modal di Indonesia}

Sekitar awal abad ke-19 pemerintah kolonial Belanda mulai membangun perkebunan secara besar-besaran di Indonesia. Sebagai salah satu sumber dana adalah dari para penabung yang telah dikerahkan sebaik-baiknya. Para penabung tersebut terdiri dari orang-orang Belanda dan Eropa lainnya yang penghasilannya sangat jauh lebih tinggi dari penghasilan penduduk pribumi.Atas dasar itulah maka pemerintahan kolonial waktu itu mendirikan pasar modal. Setelah mengadakan persiapan, maka akhirnya berdiri secara resmi pasar modal di Indonesia yang terletak di Batavia (Jakarta) pada tanggal 14 Desember 1912 dan bernama Vereniging voor de Effectenhandel (bursa efek) dan langsung memulai perdagangan ${ }^{10}$.

${ }^{8}$ http://www.ojk.go.id/sharia-capital-id di akses tanggal 9 September 2019

9 Saniman Widodo, Analisis pengruh rasio aktifitas, rasio profitabilitas, dan rasio pasar terhadap return saham syariah dan kelompok Jakarta Islamic indeks (JII) tahun 2003-2005, hal. 23

${ }^{10}$ http://www.idx.co.id/id-id/beranda/tentangbei/sejarah.aspxdi akses tanggal 4 agustus 2019 
Secara singkat, tonggak perkembangan pasar modal di Indonesia dapat dilihat sebagai berikut ${ }^{11}$ :

1. 14 Desember 1912: Bursa Efek pertama di Indonesia dibentuk di Batavia oleh Pemerintah Hindia-Belanda

2. 1914-1918: bursa efek di Jakarta ditutup selama Perang Dunia I

3. 1925-1942: bursa efek di Jakarta di buka kembali bersama dengan bursa efek di Semarang dan Surabaya

4. Awal tahun 1939: karena isu politik (Perang Dunia II) bursa efek di Semarang dan Surabaya ditutup

5. 1942-1952: bursa efek di Jakarta ditutup kembali selama perang dunia II

6. 1952: Bursa Efek di Jakarta diaktifkan kembali dengan UUD Pasar Modal 1952, yang dikeluarkan oleh Menteri Kehakiman (Lukman Wiradinata) dan Menteri Keuangan (Prof. Dr. Sumitro Djojohadikusumo). Instrumen yang diperdagangkan yaitu Obligasi Pemerintah RI (1950)

7. 1956: program nasionalisasi perusahaan Belanda. Bursa efek semakin tidak aktif

8. 1956-1977: perdagangan di bursa efek fakum

9. 10 agustus 1977: bursa efek diresmikan kembali oleh Presiden Soeharto. BEJ dijalankan di bawah Bapepam. Tanggal 10 agustus diperingati sebagai HUT Pasar Modal. Pengaktifan kembali pasar modal ini juga ditandai dengan go public PT Semen Cibonang sebagai emiten pertama

10.1977-1987: perdagangan di bursa efek sangat lesu. Jumlah emiten hingga1987 baru mencapai 24. Masyarakat lebih memilih instrumen perbankan dibandingkan instrumen pasar modal

11.1987: ditandai dengan hadirnya paket desember 1987 (PAK-DES 87) yang memberikan kemudahan bagi perusahaan untuk melakukan penawaran umum dan investor asing menanamkan modal di Indonesia

${ }^{11}$ Andri Soemitra, Bank dan Lembaga Keuangan Syariah, (Jakarta: Kencana, 2010), cet ke-2, h.114-117 
12.1988-1990: paket deregulasi dibidang perbankan dan pasar modal diluncurkan. Pintu BEJ terbuka untuk asing. Aktivitas bursa terlihat meningkat

13. 2 juni 1988: Bursa Paralel Indonesia (BPI) mulai beroperasi dan dikelola oleh Persatuan Perdagangan Uang dan Efek (PPUE), sedangkan organisasinya terdiri dari broker dan dealer.

14. Desember 1988: pemerintah mengeluarkan paket desember (PAKDES '88) yang memberikan kemudahan perusahaan untuk go punlic dan beberapa kebijakan lain yang positif bagi pertumbuhan pasar modal

15. 16 Juni 1989: Bursa Efek Surabaya (BES) mulai beroperasi dan dikelola oleh perseroan terbatas milik swasta yaitu PT Bursa Efek Surabaya

16. 13 Juli 1992: swastanisasi BEJ; Bapepam berubah menjadi Badan Pengawas Pasar Modal. Tanggal ini diperingati sebagai HUT BEJ

17. 22 Mei 1995: sistem operasi perdagangan di BEJ dilaksanakan dengan sistem computer JATS (Jakarta Automated Trading Systems)

18. 10 November 1995: Pemerintah mengeluarkan UU No. 8 tahun 1995 tentang Pasar Modal. UU ini mulai diberlakukan mulai Januari 1996

19. 1995: Bursa Paralel Indonesia marger dengan Bursa Efek Surabaya

20.3 Juli 1997: lahir danareksa syariah oleh PT Danareksa Investent Management

21.2000: sistem perdagangan tanpa warkat (scripless trading) mulai diaplikasikan di pasar modal Indonesia.

22. 3 Juli 2003: BEJ bekerjasama dengan PT Danareksa Investment Management meluncurkan Jakarta Islamic Index yang bertujuan untuk memandu investor yang ingin menanamkan dananya secara syariah.

23. 2002: BEJ mulai mengaplikasikan sistem perdagangan jarak jauh (remote trading)

24. 4 Maret 2003: pasar modal syariah diresmikan oleh Menkeu Boediono didampingi ketua Bapepam Herwidayatmo, wakil dari MUI, wakil dari DSN pada Direksi, direksi perusahaan efek, pengurus organisasi pelaku, dan asosiasi profesi di pasar modal 
25. 2007: penggabungan BEJ dan BES berdasarkan kesepakatan RUPSLB pada tanggal 40 oktober 2007 yang kemudian dituangkan dalam Akta Penggabungan dan berganti nama menjadi PT Bursa Efek Indonesia yang resmi beroperasi sejak tanggal 1 nopember 2007.

26. 2009: Peluncuran Perdana Sistem Perdagangan Baru PT Bursa Efek Indonesia: JATS-NextG12

\section{Jakarta Islamic Index (JII)}

Pada tanggal 3 juli 2000, PT bursa Efek Indonesia bekerja sama dengn PT Danareksa Investment Management (DIM) meluncurkan indeks saham yang dibuat berdasarkan syariah islam yaitu Jakarta Islamic Index (JII). Indeks ini diharapkan menjadi tolak ukur kinerja saham-saham yang berbasis syariahserta untuk lebih mengembangkan pasar modal syariah.

Jakarta Islamic Index terdiri dari 30 saham yang dipilih dari saham-saham yang sesuai dengan syariah islam. Pada awal peluncurannya, pemilihan saham yang masuk dalam kriteria syariah melibatkan pihak Dewan Pengawas Syariah PT Danareksa Investment Management. Akan tetap seiring perkembangan pasar, tugas pemilihan saham-saham tersebut dilakukan oleh Bapepam-LK, bekerja sama dengan Dewan Syariah Nasional. Hal ini tertuang dalam peraturan Bapepam - LK Nomor II.K.1 tentang kriteria dan penerbitan daftar efek syariah.

Kriteria pemilihan saham yang memenuhi prinsi-prinsip syariah dari sekian banyak emiten yang kegiatan usahanya belum sesuai dengan syariah, sehingga saham-saham tersebut secara otomatis belum dapat dimasukkan dalam perhitungan Jakarta Islamic Index.

Menurut Nurhayati \& Wasulah, penyertaan modal secara syariah tidak diwujudkan dalam bentuk saham syariah maupun non-syariah, melainkan pada saham yang memenuhi kriteria syariah. BEJ bekerja sama dengan Dewan Pengawas Syariah PT Danareksa Investment Management (DIM) telah mengembangkan Jakarta Islamic Index (JII). JII dimaksudkan sebagai tolok ukur (benchmark) untuk mengukur suatu investasi pada saham dengan basis syariah. agustus 2019

${ }^{12}$ http://www.idx.co.id/id-id/beranda/tentangbei/sejarah.aspx di akses tanggal 4 
Melalui indeks diharapkan dapat meningkatkan kepercayaan investor untuk mengembangkan investasi dalam ekuiti secara syariah.

BEI menentukan dan melakukan seleksi saham syariah yang menjadi konsisten JII. Adapun kriteria likuiditas yang digunakan dalam menyeleksi 30 saham syariah yang menjadi konsisten JII adalah sebagai berikut:

1. Saham syariah yang masuk dalam konsisten Indeks Saham Syariah Indonesia (ISSI) telah tercatat selama 6 bulan terakhir

2. Dipilih 60 saham berdasarkan urutan rata-rata kapitalisasi pasar tertinggi selama 1 tahun terakhir

3. Dari 60 saham tersebut, kemudian dipilih 30 saham berdasarkan rata-rata nilai transaksi harian di pasar reguler tertinggi

4. 30 saham yang tersisa merupakan saham yang terpilih ${ }^{13}$

Kriteria pemilihan saham dalam JII menurut Dewan Pengawas Syariah PT DIM (Danareksa Investment Management) harus melalui filter syariah terlebih dahulu. Berikut ini 4 syarat yang harus dipenuhi agar saham-saham tersebut dapat masuk kedalam JII:

1.) Emiten tidak menjalankan usaha perjudian dan permainan yang tergolong judi atau perdagangan yang dilarang

2.) Bukan lembaga keuangan konvensional yang menerapkan sistem riba, termasuk perbankan dan asuransi konvensional

3.) Usaha yang dilakukan bukan memproduksi, mendistribusikan, dan memperdagangkan makanan/minuman haram

4.) Tidak menjalankan usaha produksi, mendistribusikan, dan menyediakan barang/jasa yang merusak moral dan bersifat mudharat. ${ }^{14}$

\section{Metode Penelitian}

\section{Jenis Penelitian}

Jenis penelitian yang digunakan penulis dalam penelitian ini adalah jenis penelitian kuantitatif. Penelitian kuantitatif adalah suatu proses menemukan

${ }^{13}$ www.idx.com di akses pada tanggal 9 september 2019

14 Repository.umy.ac.id, diakses pada tanggal 16 februari 2019 
pengetahuan yang menggunaan data berupa angka sebagai alat untuk menganalisis keterangan mengenai apa yang ingin diketahui. ${ }^{15}$ penelitian ini menggunakan analisis data statistic melalui metode analisis regresi sederhna, untuk mengukur pengaruh pertumbuhan laba terhadap harga saham pada perusahaan, studi kasus pada perusahaan yang masuk di Jakarta Islamic Index.

\section{Pendekatan Penelitian}

Didalam metode penelitian kuantitatif terdapat dua jenis metode pendekatan yang digunakan yaitu metode eksperimen dan metode survei. Metode penelitian eksperimen adalah metode penelitian yang digunakan untuk mencari pengaruh treatment tertentu (perlakuan) dalam kondisi yang terkontrol (laboratorium). ${ }^{16}$ Kerlinger (1973) Metode penelitian survei adalah peneitian yang dilakukan pada populasi besar maupun kecil, tetapi data yang dipelajar adalah data yang diambil dari sampel yang diambil dari populasi tersebut, sehingga ditemukan kejadian-kejadian relatif, distribusi dan hubungan antara varianel sosiologis dan psikologis.

(David Kline: 1980) Penelitian survei pada umumnya dilakukan untuk mengambil suatu generalisasi dari pengamatan yang tidak mendalam. Walaupun metode survei ini tidak menerlukan kelompok kontrol seperti halnya pada metode eksperimen, namun generalisasi yang dilakukan bisa lebih akurat bila digunkan sampel yang representatif.

Berdasarkan uraian diatas penulis menggunakan metode pendekatan penelitian survei, Berdasarkan jumlah data haraga saham yang terdaftar di Jakarta Islamic Index (JII)

15 Mohamad Kasiran, Metode Penelitian Kuantitatif-Kualitatif, Malang : UIN malang Press, 2008, hal. 149

16 Sugiyono, Metode penelitian dan Pengembangan, Bandung : Alfabeta, 2016, hal. 14 , cet- ke-2 


\section{Populasi dan Sampel,}

\section{a. Populasi}

Burhan Bungin, Populasi adalah serumpun atau kelompok abjek yang menjadi sasaran penelitian. Oleh karenanya, populasi penelitian merupakan keseluruhan (universal) dari objek penelitian yang dapat berupa manusia, hewan, tumbuh-tumbuhan, udara, gejala nilai peristiwa, sikap hidup dan sebagainya, sehingga objek ini dapat menjadi sumber data penelitian. ${ }^{17}$

Dalam penelitian ini yang menjadi populasi adalah harga saham yang masuk Di Jakarta Islamic Index dari tahun 2016 sampai dengan tahun 2018.maka total yang digunakan sebanyak 90 data laporan keuangan

\section{b. Sampel}

Sampel adalah bagian dari jumlah dan karakteristik yang dimiliki oleh populasi tersebut. Sampel yang digunakan yaitu totalnya 90 data laporan keuangan di setiap perusahaan yang terdaftar di Jakarta Islamic Indexdi tiap-tiap tahun yaitu pada tahun 2016 - 2018. Berikut ini adalah daftar perusahaan yang menjadi sampel penelitian:

Tabel 3.1

Total perusahaan di tiga tahun terakhir yang terdaftar di Jakarta Islamic Index

\begin{tabular}{|c|c|c|c|c|c|}
\hline No & Kode saham 2016 & No & Kode saham 2017 & No & Kode saham 2018 \\
\hline 1 & & & & & \\
\hline 2 & AALI & 1 & BRPT & 1 & BRPT \\
\hline 3 & ADHI & 2 & CTRA & 2 & CTRA \\
\hline 4 & ADRO & 3 & ADRO & 3 & ADRO \\
\hline 5 & AKRA & 4 & AKRA & 4 & AKRA \\
\hline 6 & ANTM & 5 & ANTM & 5 & ANTM \\
\hline 7 & ASII & 6 & ASII & 6 & ASII \\
\hline 8 & BSDE & 7 & BSDE & 7 & BSDE \\
\hline 9 & ICBP & 8 & ICBP & 8 & ICBP \\
\hline 10 & INCO & 9 & INCO & 9 & INCO \\
\hline 11 & INDF & 10 & INDF & 10 & INDF \\
\hline
\end{tabular}

17 Burhan Bungi, Metodologi Penelitian Kuantitatif Komunikasi, Ekonomi dan Kebijakan Publik serta ilmu-ilmu sosial lainnya, Jakarta : Kencana. 2008, hal. 2009 
Eksistensi Pertumbuhan Laba pada Perusahaan di Jakarta Islamic Index (JII) (Tahun 2016-2018)

\begin{tabular}{|l|c|c|c|c|c|}
12 & KLBF & 12 & KLBF & 12 & KLBF \\
\hline 13 & LPKR & 13 & LPKR & 13 & CPIN \\
\hline 14 & LPPF & 14 & LPPF & 14 & LPPF \\
\hline 15 & LSIP & 15 & LSIP & 15 & ITMG \\
\hline 16 & MIKA & 16 & TPIA & 16 & TPIA \\
\hline 17 & MYRX & 17 & MYRX & 17 & INTP \\
\hline 18 & PGAS & 18 & PGAS & 18 & PGAS \\
\hline 19 & PTBA & 19 & PTBA & 19 & PTBA \\
\hline 20 & PTPP & 20 & PTPP & 20 & PTPP \\
\hline 21 & PWON & 21 & PWON & 21 & INDY \\
\hline 22 & SILO & 22 & WSBP & 22 & WSBP \\
\hline 23 & SMGR & 23 & SMGR & 23 & SMGR \\
\hline 24 & SMRA & 24 & SMRA & 24 & SMRA \\
\hline 25 & SSMS & 25 & SCMA & 25 & SCMA \\
\hline 26 & TLKM & 26 & TLKM & 26 & TLKM \\
\hline 27 & UNTR & 27 & UNTR & 27 & UNTR \\
\hline 28 & UNVR & 28 & UNVR & 28 & UNVR \\
\hline 29 & WIKA & 29 & WIKA & 29 & WIKA \\
\hline 30 & WSKT & 30 & WSKT & 30 & JSMR \\
\hline
\end{tabular}

\section{Jenis dan Sumber Data}

\section{a. Jenis Data}

Jenis data yang digunakan dalam penelitian ini adalah data kuantitatif yaitu data yang berbentuk angka. Data diperoleh dalam bentuk yang sudah jadi, atau data yang berasal Laporan keuangan yang sudah dikumpulkan dan sudah diaudit oleh pihak lain yaitu perusahaan.

\section{b. Sumber Data}

Sumber data yang dimaksud dalam hal ini adalah "Subjek dari mana data dapat diperoleh". ${ }^{18}$ Sumber data yang digunakan dalam penelitian ini adalah data sekunder. Data sekunder adalah data yang sudah tersedia dan dikumpulkan pihak lain. Maka dapat diperoleh data melalui dokumen atau arsip perusahaan yang ada kaitannya dengan pembahasan skripsi ini. Data sekunder yang digunakan dalam penelitian ini berasal dari Laporan Keuangan tahun 2016-2018. Data saham yang dipakai adalah harga pasar saham pada saat publikasi laporan keuangan dan tujuh hari setelah publikasi laporan keuangan. Sedangkan data akuntansi yang dipakai

18 Suharsimi arikunto, Prosedur Penelitian Suatu Pendekatan Praktik, Jakarta : Pt Rineka Cipta, 1992, Ed. Revisi, Cet. VIII, hal. 102 
adalah laporan keuangan berupa neraca dan laporan laba bersih yang telah diaudit oleh perusahaan Jakarta Islamic Index yang terdaftar di Bursa Efek Indonesia melalui website www.idx.co.id dan yahoo.finance.co.id.

\section{Metode Analisis Data}

Metode analisis data yang digunakan dalam penelitian ini adalah analisis data kuantitatif. Dimana analisis data ini dilakukan untuk mengetahui apakah ada pengaruh pertumbuhan laba terhadap harga saham pada perusahaan, studi kasus pada perusahaan yang masuk Di Jakarta Islamic Index (JII). Baik pengaruh secara simultan maupun parsial.

Pada penelitian ini, peneliti menggunakan alat bantu SPSS Versi 22 untuk mempermudah proses pengolahan data. Program tersebut akan menghasilkan output berupa hasil pengolahan data yang telah dikumpulkan, kemudian hasil pengolahan data tersebut akan dilakukan analisis terhadap hasil pengolahan data tesebut. Adapun pengukuran tersebut sebagai berikut:

\section{Analisis Statistik Deskriptif}

Data dalam penelitian ini dianalisis dengan statistik deskriptif. Statistik deskriptif memberikan gambaran tentang distribusi frekuensi variabel-variabel penelitian, nilai maksimum, minimum, rata-rata dan standar deviasi. Adapun analisis yang digunakan adalah; analisis regresi sederhana, analisis uji asumsi klasik, analisis uji normalitas, uji regresi linear sederhana, uji koefisien korelasi, dan uji hipotesis.

\section{Hasil Penelitian}

\section{Analisis Statistik Deskriptif Data}

Dalam penelitian ini tujuan yang ingin dicapai oleh peneliti adalah apakah pertumbuhan laba berpengaruh secara parsial terhadap harga saham di perusahaan Jakarta Islamic Index. Untuk mengimplementasikan hal tersebut maka dilakukan pengumpulan data laporan keuangan dari perusahaan yang termasuk didalam perusahaan Jakarta Islamic Index pada tahun 2016 - 2018. Berikut data pertumbuhan laba dan Harga Saham yang masuk di Perusahaan Jakarta Islamic Index pada tahun 2016-2018 
Eksistensi Pertumbuhan Laba pada Perusahaan di Jakarta Islamic Index (JII) (Tahun 2016-2018)

Tabel 4.1

\begin{tabular}{|c|c|c|c|c|c|c|c|c|c|}
\hline \multicolumn{4}{|c|}{$\begin{array}{c}\text { Data Perusahaan Jakarta Islamic Index } \\
\text { Tahun } 2016\end{array}$} & \multicolumn{3}{|c|}{$\begin{array}{l}\text { Data Perusahaan Jakarta Islamic } \\
\text { Index Tahun } 2017\end{array}$} & \multicolumn{3}{|c|}{$\begin{array}{l}\text { Data Perusahaan Jakarta Islamic } \\
\text { Index Tahun } 2018\end{array}$} \\
\hline No & $\begin{array}{l}\text { Kode } \\
\text { saham }\end{array}$ & $\begin{array}{c}\text { Pertumbuhan } \\
\text { laba }\end{array}$ & $\begin{array}{l}\text { Harga } \\
\text { saham }\end{array}$ & $\begin{array}{l}\text { Kode } \\
\text { saham }\end{array}$ & $\begin{array}{c}\text { Pertumbuh } \\
\text { an laba }\end{array}$ & $\begin{array}{l}\text { Harga } \\
\text { saham }\end{array}$ & $\begin{array}{l}\text { Kode } \\
\text { saham }\end{array}$ & $\begin{array}{c}\text { Pertumb } \\
\text { uhan } \\
\text { laba }\end{array}$ & Harga saham \\
\hline 1 & AALI & 2,40 & 16775 & BRPT & 0,14 & 2275 & BRPT & 0,27 & 2390 \\
\hline 2 & ADHI & 1,00 & 2080 & CTRA & 1,00 & 1185 & CTRA & 0,25 & 1010 \\
\hline 3 & ADRO & 0,16 & 1695 & ADRO & 0,57 & 1860 & ADRO & 0,11 & 1215 \\
\hline 4 & AKRA & 0,17 & 6000 & AKRA & 0,49 & 6350 & AKRA & 0,20 & 4250 \\
\hline 5 & ANTM & 1,05 & 895 & ANTM & 1,09 & 625 & ANTM & 5,43 & 765 \\
\hline 6 & ASII & 0,41 & 8275 & ASII & 0,25 & 8300 & ASII & 0,15 & 8225 \\
\hline 7 & BSDE & 0,16 & 1755 & BSDE & 1,74 & 1700 & BSDE & 0,74 & 1225 \\
\hline 8 & ICBP & 0,24 & 8575 & ICBP & 0,02 & 8900 & ICBP & 0,31 & 10450 \\
\hline 9 & INCO & 0,96 & 2820 & INCO & 7,01 & 2890 & INCO & 2,96 & 3260 \\
\hline 10 & INDF & 0,42 & 7925 & INDF & 0,03 & 7625 & INDF & 0,03 & 7450 \\
\hline 11 & INTP & 887,23 & 15400 & EXCL & 0,52 & 2960 & EXCL & 0,38 & 1980 \\
\hline 12 & KLBF & 0,15 & 1515 & KLBF & 0,05 & 1690 & KLBF & 0,02 & 1520 \\
\hline 13 & LPKR & 0,20 & 720 & LPKR & 0,30 & 488 & CPIN & 0,82 & 7225 \\
\hline 14 & LPPF & 0,13 & 15125 & LPPF & 0,06 & 10000 & LPPF & 0,42 & 5600 \\
\hline 15 & LSIP & 0,05 & 1740 & LSIP & 0,24 & 1420 & ITMG & 0,55 & 20250 \\
\hline 16 & MIKA & 0,22 & 2570 & TPIA & 0,02 & 6000 & TPIA & 0,07 & 5925 \\
\hline 17 & MYRX & 3,70 & 169 & MYRX & 0,25 & 110 & INTP & 0,38 & 18450 \\
\hline 18 & PGAS & 0,24 & 2700 & PGAS & 0,35 & 1750 & PGAS & 0,55 & 2120 \\
\hline 19 & PTBA & 0,02 & 2500 & PTBA & 1,23 & 2460 & PTBA & 0,12 & 4300 \\
\hline 20 & PTPP & 0,36 & 3810 & PTPP & 0,50 & 2640 & РТPP & 0,14 & 1805 \\
\hline 21 & PWON & 0,27 & 565 & PWON & 1136,64 & 685 & INDY & 0,40 & 1585 \\
\hline 22 & SILO & 0,60 & 10900 & WSBP & 0,58 & 408 & WSBP & 0,10 & 376 \\
\hline 23 & SMGR & 0,02 & 9175 & SMGR & 1,00 & 9900 & SMGR & 1869,30 & 11500 \\
\hline 24 & SMRA & 0,44 & 1325 & SMRA & 879,06 & 945 & SMRA & 0,30 & 805 \\
\hline 25 & SSMS & 0,09 & 1400 & SCMA & 0,13 & 2480 & SCMA & 0,12 & 1870 \\
\hline 26 & TLKM & 0,25 & 3980 & TLKM & 0,69 & 4440 & TLKM & 0,17 & 3750 \\
\hline 27 & UNTR & 0,41 & 21250 & UNTR & 0,05 & 35400 & UNTR & 0,14 & 27350 \\
\hline 28 & UNVR & 0,09 & 38800 & UNVR & 0,10 & 55900 & UNVR & 0,30 & 45400 \\
\hline 29 & WIKA & 1,00 & 2360 & WIKA & 0,12 & 1550 & WIKA & 0,53 & 1655 \\
\hline 30 & WSKT & 0,73 & 2550 & WSKT & 1,32 & 2210 & JSMR & 0,03 & 4280 \\
\hline
\end{tabular}

\section{Hasil Analisis Data}

\section{a. Uji Normalitas}

Uji normalitas adalah sebuah uji yang dilakukan dengan tujuan untuk menilai sebaran data sebuah kelompok data atau variabel, apakah sebaran data 
tersebut berdistribusi normal atau tidak. Dalam penelitian ini peneliti menggunakan uji kolmogrov smirnov.

Uji kolmogrov smirnov merupakan pengujian normal yang banyak dipakai, terutama setelah adanya banyak program statistic yang beredar. Konsep dasar uji kolmogrov smimov adalah dengan membandingkan distribusi data ( yang akan di uji normalitasnya ) dengan distribusi normal baku. Distribusi normal baku adalah data yang telah ditransformasi ke dalam bentuk Z-score dan diasumsikan normal. Jadi sebenarnya uji kolmogrov smirnov adalah uji beda antara data yang diuji normalitasnya dengan data normal baku.

Pada uji Kolmogrov smormov, jika signifikansi di bawah 0,05 berarti data yang akan diuji mempunyai perbedaan yang signifikan dengan data normal baku, berarti data tersebut tidak normal. Berikut adalah uji kolmogrov smirnov yang diolah dalam aplikasi SPSS 22.

Tabel. 4.1

Uji Normalitas Data

One-Sample Kolmogorov-Smirnov Test

\begin{tabular}{|ll|l|}
\hline & & $\begin{array}{l}\text { Unstandardized } \\
\text { Residual }\end{array}$ \\
\hline $\mathrm{N}$ & & 90 \\
Normal Parameters & & $. \mathrm{a}, \mathrm{b}$ \\
& Mean & .0000000 \\
Most Extreme Differences & Std. Deviation & .57443140 \\
& Absolute & .080 \\
& Positive & .080 \\
Test Statistic & Negative & -.058 \\
Asymp. Sig. (2-tailed) & & .080 \\
\hline
\end{tabular}

Sumber: Output SPSS 22

Berdasarkan hasil uji normalitas data untuk variabel Pertumbuhan Laba (X) terhadap Harga Saham (Y) secara simultan di atas dapat dilihat pda kolom Asymp.Sig (2-tailed) menunjukan tingkat signifikansi 0,200. Signifikansi tersebut lebih besar dari 0,05. Hal ini menunjukan bahwa data tersebut memenuhi asumsi normal. 


\section{b. Uji Koefisien Korelasi}

Koefisien korelasi ( $\mathrm{R}$ ) menunjukan seberapa besar pengaruh variabel bebas terhadap variabel terikat secara parsial. Nilai R ini menunjukan seberapa besar kemampuan variabel bebas (pertumbuhan laba) secara individual mempengaruhi variabel terikat (Harga Saham) dalam Penelitian ini

\section{Model Summary}

\begin{tabular}{|l|c|r|r|r|}
\hline Model & $\mathrm{R}$ & R Square & $\begin{array}{c}\text { Adjusted R } \\
\text { Square }\end{array}$ & $\begin{array}{c}\text { Std. Error of } \\
\text { the Estimate }\end{array}$ \\
\hline 1 & $.095^{\mathrm{a}}$ & .009 & -.002 & .57769 \\
\hline
\end{tabular}

Sumber: Output SPSS 22

Dari hasil uji koefisien korelasi yang telah dilakukan terhadap data yang ada, dapat dipahami bahwa pada tabel model summary ini menunjukan nilai $\mathrm{R}$ sebesar 0,095. Hal ini berarti menunjukan bahwa variabel independen yakni pertumbuhan laba berpengaruh $09,5 \%$ terhadap harga saham pada perusahaan yang terdaftar di Jakarta Islamic Index sedangkan 90,5\% yang didapat dari 100\% 0,095\% ditentukan oleh variabel lain yang tidak termasuk dalam analisis ini atau penelitian regresi ini. Nilai ini berarti hubungan antara variabel independen yaitu pertumbuhan laba terhadap variabel dependen yaitu harga saham adalah sangat lemah.

Seperti yang telah diketahui bahwa nilai R sebesar 0,095\% nilai tersebut menunjukan besaran pengaruh variabel independen (pertumbuhan laba) terhadap variabel dependen (harga Saham). Variabel independen yang dimaksud adalah pertumbuhan laba dan 90,5\% dipengaruhi oleh variabel lain, seperti proyeksi kinerja perusahaan pada masa mendatang dan juga kebijakan pemerintah seperti kegiatan ekspor impor, kebijakan utang dan kebijakan penanaman modal asing

\section{c. Hasil Regresi Linear Sederhana}

Tabel 4.3

\section{Hasil Regresi Linear Sederhana}

\begin{tabular}{|c|c|c|c|c|c|c|}
\hline \multicolumn{7}{|c|}{ Coefficients $^{a}$} \\
\hline \multirow{2}{*}{\multicolumn{2}{|c|}{ Model }} & \multicolumn{2}{|c|}{ Unstandardized Coefficients } & $\begin{array}{l}\text { Standardized } \\
\text { Coefficients }\end{array}$ & \multirow[b]{2}{*}{$\mathrm{T}$} & \multirow[b]{2}{*}{ Sig. } \\
\hline & & $\mathrm{B}$ & Std. Error & Beta & & \\
\hline 1 & (Constant) & 6526.542 & 1065.340 & & 6.126 & .000 \\
\hline & $\mathrm{X}$ & 1.868 & 4.281 & .046 & .436 & .664 \\
\hline
\end{tabular}


Berdasarkan tabel diatas maka:

a. Konstanta $\mathrm{a}=6526.542$ dan koefisien $\mathrm{b}=1.868$ sehingga persamaan regresi sederhana menjadi $\mathrm{Y}=6526.542+1.868$. konstanta a sebesar 6526.542 menyatakan bahwa dengan adanya pertumbuhan laba maka harga saham pada perusahaan yang terdaftar di Jakarta Islamic Index sebesar 6526.542

b. Koefisien regresi untuk X sebesar 1.868 menyatakan bahwa apabila variabel X meningkat atau menurun sebesar satu satuan maka Y akan meningkat atau menurun pula sebesar 1.868. koefisien bernilai positif berarti terjadi hubungan positif antara pertumbuhan laba dengan harga saham pada perusahaan yang terdaftar di Jakarta Islamic Index.

Asumsi Thitunglebih besar dari pada Ttabel taraf signifikansi 0,05. Kemudian nilai alpha signifikansi 5\% (a : 5\%=0,5). Dengan demikian H0 ditolak $\mathrm{H} 1$ diterima maka terdapat pengaruh antara X dan Y. atau sebaliknya H0 diterima H1 ditolak maka tidak terdapat pengaruh antara X dan Y. tidak terdapat pengaruh antara variabel pertumbuhan laba dan harga saham menunjukan nilai Thitung lebih kecildari pada Ttabel dengan nilai 0,436 < 1,987. Dengan demikian H0 diterima H1 ditolak. Artinya variabel bebas (pertumbuhan laba) tidak berpengaruhi signifikan pada variabel terikat sebesar 0,664 lebih besar dari 0,05.

\section{d. Pembahasan Hasil Penelitian}

Pertumbuhan laba adalah perubahan presentase kenaikan laba yang diperoleh perusahaan. Pertumbuhan laba yang baik, mengisyaratkan bahwa perusahaan mempunyai keuangan yang baik, yang pada akhirnya akan meningkatkan nilai perusahaan, perusahaan dengan laba bertumbuh, dapat memperkuat hubungan antara besarnya atau ukuran perusahaan dengan tingkat laba yang diperoleh. Dimana perusahaan dengan laba bertumbuh akan memilki jumlah aktiva yang besar sehingga memberikan peluang lebih besar didalam menghasilkan profitabilitas

Penelitian ini bertujuan untuk menguji pengaruh pertumbuhan laba (X) terhadap harga saham pada perusahaan yang terdaftar di Jakarta Islamic Index. Hasil penelitian ini menunjukan bahwa variabel pertumbuhan labatidak 
berpengaruh signifkan terhadap harga saham pada perusahaan yang terdaftar di Jakarta Islamic Index. Alasan kuantitatifnya adalah karena tingkat signifikansi variabel pertumbuhan laba terhadap variabel harga saham adalah sebesar 0,664 Ttabel yang diperoleh dari Ttabel dengan taraf signifikan sebesar 0,025 (diperoleh dari 0,50:2) dari nilai df 88 (diperoleh dari $\mathrm{n}-\mathrm{k}-1$ ) dimana $\mathrm{n}$ adalah sampel, $\mathrm{k}$ adalah jumlah variabel X. 90-1-1. Dengan nilai taraf signifikan sebesar 0,025 dan nilai df sebesar 88 maka diperoleh t tabel 1.987.

Dari hasil pengujian secara parsial (uji t) antara variabel pertumbuhan laba dan harga saham menunjukan nilai Thitung lebih kecil dari pada Ttabel dengan nilai 0,436<1,987 dan memilki nilai sig sebesar 0,664 lebih besar dari 0,05. Hal ini menunjukan bahwa variabel pertumbuhan laba tidak berpengaruh signifikan terhadap harga saham pada perusahaan yang terdaftar di Jakarta Islamic Index.

Hal ini sesuai dengan penelitian yang dilakukan oleh fitriyanti tentang pengaruh pertumbuhan laba terhadap nilai saham pada perusahaan (kasus pada perusahaan yang masuk di Jakarta Islamic Index). Dengan hasil penelitian variabel pertumbuhan laba tidak berpengaruh secara signifikan terhadap nilai saham pada perusahaan (kasus pada perusahaan yang masuk di Jakarta Islamic Index). Hal ini ditunjukan oleh nilai koefisien regresi sebesar 616. Dari pengujian hipotesis ini diketahui bahwa Thitung lebih kecil dari pada Ttabel $(0,616<2,021)$, sehingga mengindikasikan bahwa pertumbuhan laba tidak berpengaruh parsial terhadap nilai saham pada perusahaan (kasus pada perusahaan yang masuk di Jakarta islamic index).

Alasan kualitatif, pertumbuhan laba tidak berpengaruh secara signifkan terhadap harga saham pada perusahaan yang terdaftar di Jakarta Islamic Index yaitudikarenakan bukan hanya pengaruh laporan keuangan khususnya pertumbuhan laba melainkan ada faktor lain seperti laba per lembar saham atau earning per share, tingkat bunga bebas risiko yang diukur dari tingkat deposito pemerintah, inflasi, berbagai regulasi ekonomi yang dikeluarkan oleh pemerintah serta tingkat kepastian operasi perusahaan dan juga disebabkan terjadinya Fluktuasi Kurs Rupiah terhadap mata uang asing19

${ }^{19} \underline{\mathrm{http}} / / /$ www.cermati.com di akses pada tanggal 6 agustus 2019 
Alasan lainnya atau faktor-faktor lain yang mempengaruhi harga saham yaitu disebabkan karena adanya faktor eksternal dan internal perusahaan (Brigham dan Houston) salah satunya adalah pengumuman industry sekuritas, seperti laporan pertemuan tahunan insider trading, volume atau harga saham perdagangan pembatasan atau penundaan trading.

\section{E. Kesimpulan}

Berdasarkan hasil penelitian dan pembahasaan mengenai pengaruh pertumbuhan laba terhadap harga saham pada perusahaan (studi pada perusahaan terdaftar di Jakarta Islamic Index), maka dapat disimpulkan bahwa tidak berpengaruh secara signifikan variabel pertumbuhan laba terhadap harga saham pada perusahaan (studi pada perusahaan terdaftar di Jakarta Islamic Index) dari hasil pengujian secara parsial (uji t) antara variabel pertumbuhan laba dan harga saham menunjukan Thitung lebih kecil dari pada Ttabel dengan nilai $0,436<1,987$ dan memiliki nilai sig sebesar 0,664 lebih besar dari 0,05. Dari hasil pengujian $\mathrm{T}$ tersebut disimpulkan bahwa variabel pertumbuhan laba tidak berpengaruh signifikan terhadap harga saham pada perusahaan (studi pada perusahaan terdaftar di Jakarta Islamic Index) karena terdapat pengaruh lain pada harga saham salah satunya yaitu fluktuasi kurs rupiah terhadap mata uang asing sebab hal ini akan mempengaruhi naik turunnya harga saham

\section{DAFTAR PUSTAKA}

Ahmad Rodoni dan Prof Dr. Abdul Hamid Lembaga Keuangan Syariah, Zikrul Hakim, Jakarta Timur

Arikunto Suharsimi, Prosedur Penelitian Suatu Pendekatan Praktik, Jakarta : Pt Rineka Cipta, 1992, Ed. Revisi, Cet. VIII,

Bungi Burhan, Metodologi Penelitian Kuantitatif Komunikasi, Ekonomi dan Kebijakan Publik serta ilmu-ilmu sosial lainnya, Jakarta : Kencana. 2008,

Bursa Efek indonesia. 2017. BEI Kembali Raih Penghargaan Global Islamic Finance Award,di akses pada tanggal 7 Oktober 2017 pukul 17.30 dari http://www.idx.co.id/Beranda/BeritadanPengumuman/SiaranPers/ReadP ressRelease/tabid/191/ItemID/e65caea3-1c2e-44e7a46e48101550284b/language/id- ID/Default.aspx 
Fahmi Irham, Bank dan lembaga keuangan lainnya teori dan aplikasi, (Bandung, Alfabeta , 2014).

Febrianti, Sukma, Analisis perbandingan kinerja Indeks saham syariah dengan indeks saham konvensional periode 2015 -2017 (studi kasus pada JII dan Lq45), prosiding sendi_U 2018

Halim, Abdul. 2015. Analisis Investasi dan Aplikasinya. Jakarta : Salemba Empat. Hartono, Jogiyanto. 2015. Teori Portofolio dan Analisis Investasi. Yogyakarta: BPFE-YOGYAKARTA.

Hidayat. Taufik. 2011. Buku Pintar Investasi Syariah. Jakarta: PT TransMedia.

Huda, Nurul dan Mustafa Edwin Nasution. 2008. Investasi pada Pasar Modal Syariah. Jakarta: Kenacana Prenada Media Group.

Kartika, U. 0 \& Wahyuni, N. 2011. Pengaruh Perubahan Komposisi Jakarta Islamic Index Terhadap Return Saham. Jurnal El-Qudwah. Vol. 1, No. 5, pp: 1-21.

Kasanah Herli Ruliatul, Warokinasih Saparilah, Anbalisis perbandingan Return dan Risk Saham Syariah dengan Saham Konvensional (studi pada Jakarta Islamic Index (JII) dan IDX30 periode 2014-2016), Jurnal Administrasi Bisnis (JAB),vol 58 no. 2, mei , 2018

Kasiran Mohamad, Metode Penelitian Kuantitatif-Kualitatif, Malang : UIN malang Press, 2008,

Muthoharoh, Sutapa, Jurnal Akuntansi Indonesia, Vol. 3 No. 2 Juli 2014

Nachrowi, Pendekatan Populer dan Praktis Ekonometrika Untuk Analisis Ekonomi dan Keuangan. Fakultas Ekonomi Universitas Indonesia, 2006,

Naha, S \& Roy, M. 2011. Product Market Competition And Capital Structure Of Firms: The Indian Evidence. Journal of Quantitative Economics. Vol. 9, No. 2, pp: 140-153.

Nunnaly, Metode Statistika, Bandung : Tarsito, 1967,

Riduwan, Dasar-dasar statistic, (Bandung : ALFABETA, 2003)

Rosyida, Ajeng Gama. 2015. Perbandingan Tingkat Pengembalian (Return), Resiko dan Koefisien Variasi pada Saham Syariah dan Saham Non Syariah di Bursa Efek Indonesia (BEI) Periode 2011 2013”. JESTT. Vol. 2 No. 4.

Rusdin, Pasar modal teori, masalah, dan kebijakan dalam praktik,(Bandung, Alfabeta, 2008).

Saniman Widodo, Analisis pengruh rasio aktifitas, rasio profitabilitas, dan rasio pasar terhadap return saham syariah dan kelompok Jakarta Islamic indeks (JII) tahun 2003-2005,

Sholihan, Aminatus, Perbandingan Kinerja Indeks Saham Syariah dengan Indeks Konvensional Periode 2011-2016 (Studi Kasus pada ISSI dan IHSG

Soemitra Andri, Bank dan Lembaga Keuangan Syariah, (Jakarta: Kencana, 2010), cet ke-2, 
Sudarsono Heri, Bank dan Lembaga keuangan syariah deskripsi dan ilustrasi, (Yogyakarta, Ekonosia, 2012).

Sugiyono, Metode penelitian dan Pengembangan, Bandung : Alfabeta, 2016, hal. 14, cet- ke-2

Sulistyo, Aloysius, 2004, “Analisis Pengaruh Faktor Fundamental Perusahaan terhadap Return Saham di Busa Efek Jakarta", Tesis Magister Manajemen Undip, Semarang.

Sunariyah, 2000, "Pengantar Pengetahuan Pasar Modal", Edisi Kedua, UUP AMP YKPN, Yogyakarta.

Sunarto, 2001, "Pengaruh Rasio Profitabilitas dan Leverage terhadap Return Saham Perusahaan Manufaktur di BEJ", Majalah Gema, Vol 6, Maret, Stikubank, Semarang:

Supranto, 2004, "Statistik Pasar Modal Keuangan dan Perbankan", Rineka Cipta, Jakarta.

Susilo, Bambang, Pasar Modal Mekanisme Perdagangan Saham, Analisis Sekuritas,dan Strategi Investasi di Bursa Efek Indonesia (BEI), Cet. Pertama, Yogyakarta: UPP STIM YKPN, 2009)

Suwandi, 2003. "Pengaruh Beberapa Faktor Fundamental Perusahaan Terhadap Return Saham (Studi Kasus Pada Saham-saham IQ-45)", Tesis Magister Manajemen Undip, Semarang.

\section{Internet;}

www.idx.co.id,

http://www.ojk.go.id/sharia-capital-id

http://www.idx.co.id/id-id/beranda/tentangbei/sejarah.aspx

Htttp://text-id.123dok.com

Eprints.polri.ac.id

www.idx.com

Repository.umy.ac.id,

http://www.idx.co.id/id-id/beranda/tentangbei/sejarah.aspx 